UDK 536.46

\author{
Orlovskaya S.G. \\ I. I. Mechnikov's Odessa National University \\ E-mail: svetor25@gmail.com
}

\title{
Physicochemical mechanisms of the growth of oxide crystals on the surface of tungsten conductors heated by electric current
}

\begin{abstract}
Physical and mathematical modeling of stationary thermal modes of heating and oxidation of tungsten conductors heated by electric current in air has been carried out. The dependences of the stationary temperature of the conductor on the strength of the heating current are obtained. The critical values of the current strength are found, which determine the transitions to the unsteady oxidation regime. The results of calculating the temperature regimes describe well the experimental data obtained by us using the electrothermographic method.

As a result of experimental studies, the features of the appearance and growth of crystalline oxide structures on the surface of an oxidizing tungsten conductor have been studied. The temperatures at which filamentous crystals appear on the tungsten surface are determined, and the regularities of their growth are investigated. A physicochemical mechanism of the formation and growth of crystalline oxide structures on the surface of a tungsten conductor is proposed. It was found that carbon particles, which are part of the impurity, are the reason for the formation of nitrate crystals of tungsten trioxide on the basic oxide. With an increase in the temperature of the sample, the filaments grow, branch out and transform into dendritic structures of a complex bush-like shape. It has been proven that the rapid growth of crystal structures occurs due to the deposition of clusters and microgranules of $\mathrm{WO}_{3}$ oxide from the gas phase on the crystallization centers on the surface of the conductor. At the initial stage, these are impurity particles or mechanical inhomogeneities of the basic oxide, then a growing crystal. Clusters arise due to large temperature gradients at the surface of the conductor. It has been established that carbon atoms can migrate along the branches of oxide crystal structures.

It was found that at the initial stage the crystals grow more intensively in the longitudinal direction. However, upon reaching a certain height, they begin to expand intensively in the transverse direction. The growth rates of crystal structures in the longitudinal and transverse directions are found.
\end{abstract}

Key words: heat and mass transfer, oxidation, temperature, tungsten, tungsten oxides, crystals.

Introduction. Tungsten oxides are promising materials for their use in solar energy, catalysis, microelectronics. Therefore, obtaining tungsten oxides with desired properties is an urgent task. Thin films of tungsten oxides can be obtained by chemical deposition, plasma spraying, but the most economical and environmentally friendly method of obtaining oxides is controlled high-temperature oxidation of metal wire heated by electric current in a controlled gaseous medium [1,2 ].

The use of tungsten oxides in the chemical industry as catalysts (dehydration of alcohols, cracking of hydrocarbons) determines the relevance of studies of temperature regimes and patterns of their formation. To solve this problem, a detailed understanding of the physicochemical mechanisms of the formation and growth of oxide crystals is required. 
The aim of the work was to study the patterns of growth of tungsten oxide crystals on the surface of tungsten samples at different temperatures; study of their structure, properties and growth kinetics.

1. Simulation of thermal regimes in the oxidation of a tungsten conductor heated by electric current. Let us consider unsteady heat and mass transfer and the kinetics of oxidation of a tungsten conductor heated by an electric current in air, the Joule heat released in this case leads to an increase in the temperature of the conductor and activates a chemical oxidation reaction on its surface. It is assumed that an oxide film is formed on the surface of the conductor, consisting of oxide $\mathrm{WO}_{3}$, the formation of which occurs in accordance with the equation:

$$
\mathrm{W}+\mathrm{O}_{3} \rightarrow \mathrm{WO}_{3} \text {. }
$$

It is known that the oxidation reaction proceeds according to the parabolic law $[3,4]$ and the rate of the chemical reaction is limited by the thickness of the oxide film:

$$
W_{O_{2}}=\frac{D_{0}}{h} \exp \left(-\frac{E}{R T}\right) n_{O_{2} s} \rho_{g}
$$

Then the density of the chemical heat release of the tungsten oxidation reaction is defined as:

$$
q_{c h}=Q \cdot W_{O_{2}}
$$

where $Q$ - the heat effect of the reaction, $\mathrm{J} / \mathrm{kg} \mathrm{O} \mathrm{O}_{2} ; W_{\mathrm{O}_{2}}$ - oxidation rate, calculated by oxygen, $\mathrm{kg} /\left(\mathrm{m}^{2} \mathrm{~s}\right) ; h$ - the thickness of the oxide film, $\mathrm{m} ; n_{\mathrm{O}_{2} \mathrm{~S}}$ - relative mass concentration of oxygen on the metal surface; $\rho_{g}$-air density, $\mathrm{kg} / \mathrm{m}^{3} ; D_{0}$ - diffusion coefficient of oxygen through the oxide layer, $\mathrm{m}^{2} / \mathrm{s} ; E$ - activation energy, $\mathrm{J} / \mathrm{mol} ; R$ - universal gas constant, $\mathrm{J} /(\mathrm{mol} \cdot \mathrm{K})$.

Molecular-convective heat exchange of a heated conductor with air is described by the Newton - Richmann law:

$$
q_{c}=\alpha\left(T-T_{g}\right), \quad \alpha=\frac{N u \cdot \lambda_{g}}{d},
$$

and heat exchange by radiation with the walls of the installation - by the Kirchhoff and Stefan-Boltzmann laws:

$$
q_{w}=\varepsilon \sigma\left(T^{4}-T_{w}^{4}\right)
$$

In (3) - (4): $q_{c}, q_{w}$ - the density of the molecular-convective heat flux and heat flux by radiation, $\mathrm{W} / \mathrm{m}^{2} ; T_{g}$ - gas temperature, $\mathrm{K} ; \alpha$ - heat transfer coefficient, $\mathrm{W} /\left(\mathrm{m}^{2}\right.$ $\cdot \mathrm{K}) ; \lambda_{g}-$ gas thermal conductivity coefficient, $\mathrm{W} /(\mathrm{m} \cdot \mathrm{K}) ; N u-$ the Nusselt criterion, $N u=1.18(G r \operatorname{Pr})^{\frac{1}{8}}[5] ; \quad G r-$ the Grashof number; $P r-$ the Prandtl number; $\varepsilon$ - the emissivity coefficient of tungsten; $d$-diameter of tungsten conductor, $\mathrm{m} ; T_{w}-$ temperature of the walls of the reaction system, $\mathrm{K}$.

he density of the Joule heat flux released in a conductor with a current is determined from the expression: 


$$
q_{j}=\frac{4 I^{2} \eta_{0}\left(1+\gamma\left(T-T_{0}\right)\right)}{\pi^{2} d^{3}}
$$

where $I-$ the current strength, A; $\eta_{0}-$ resistivity of tungsten at temperature $T_{0}=$ $273 \mathrm{~K}, \mathrm{Ohm} \cdot \mathrm{m} ; \gamma$-temperature coefficient of resistance, $\mathrm{K}^{-1} ; T$ - the average temperature of the conductor, $\mathrm{K}$.

Heat loss by heat output through the ends of the conductor to the currentcarrying contacts, which are at a temperature $T_{g}$, is determined by the expression [6]:

$$
q_{\lambda}=\frac{\alpha \cdot S_{L} \cdot\left(T-T_{g}\right)}{S_{d} \cdot \theta}, \quad \theta=\left(1-\frac{\sqrt{B} L \cdot \operatorname{sh} \sqrt{B} L}{2 \cdot(\operatorname{ch} \sqrt{B} L-1)}\right) \text {, }
$$

where $S_{d}=\frac{\pi d^{2}}{4}, P=\pi d, S_{L}=P L, \quad B=\frac{\alpha P}{\lambda_{W} S_{s}}$. Here L is the length of the conductor, $\mathrm{m} ; \lambda_{W}$ is the thermal conductivity coefficient of tungsten, $\mathrm{W} /\left(\mathrm{m}^{2} \mathrm{~K}\right)$.

When the tungsten conductor reaches the melting point of the oxide, it melts and then evaporates from the surface of the conductor. Evaluation of heat losses for evaporation of the oxide layer showed that at conductor temperatures close to the oxide melting temperature, they can be neglected.

Taking into account formulas (1) - (6), we write down a differential equation that determines the change in the temperature of the conductor over time:

$$
c_{W} \rho_{W} \frac{\partial T}{\partial t}=\frac{4}{d}\left(q_{j}+q_{c h}-q_{c}-q_{w}-q_{\lambda}\right), \quad T(t=0)=T_{b},
$$

where $c_{W}, \rho_{W}$ - the specific heat and density of tungsten, $\mathrm{J} /(\mathrm{kg} \cdot \mathrm{K}), \mathrm{kg} / \mathrm{m}^{3} ; T_{b}-$ the initial temperature of the conductor, $\mathrm{K}$.

For stationary conductor heating modes $\frac{\partial T}{\partial t}=0$, equation (7) will take the form:

$$
q_{j}+q_{c h}-q_{c}-q_{w}-q_{\lambda}=0
$$

Substituting the expressions for the heat flux densities into the stationarity condition, we obtain an equation linking the stationary temperature of the conductor and the current that heats it:

$$
I^{2}=\frac{\pi^{2} d^{2}}{4 \rho_{0}\left(1+\gamma\left(T-T_{0}\right)\right)}\left[\left(1+\frac{1}{\theta}\right) \alpha\left(\left(\bar{T}-T_{g}\right)\right)+\varepsilon \sigma\left(T^{4}-T_{g}^{4}\right)-Q \frac{D}{h} n_{0_{2} s} \rho_{g}\right] .
$$

Equation (9) determines stable and critical high- and low-temperature modes of heat and mass transfer and oxidation of the dart with a given initial thickness of the oxide hb at different intensities of its heating by electric current.

2. Experimental stand. To carry out experimental studies of tungsten oxidation kinetics and oxide coatings, we developed a special stand, where electrothermographic and pyrometric methods were used to measure the temperature (Fig.1). To study the surface of the conductor during the oxidation process, an optical-digital method was developed [7]. The conductor (1) was heated by means of a 


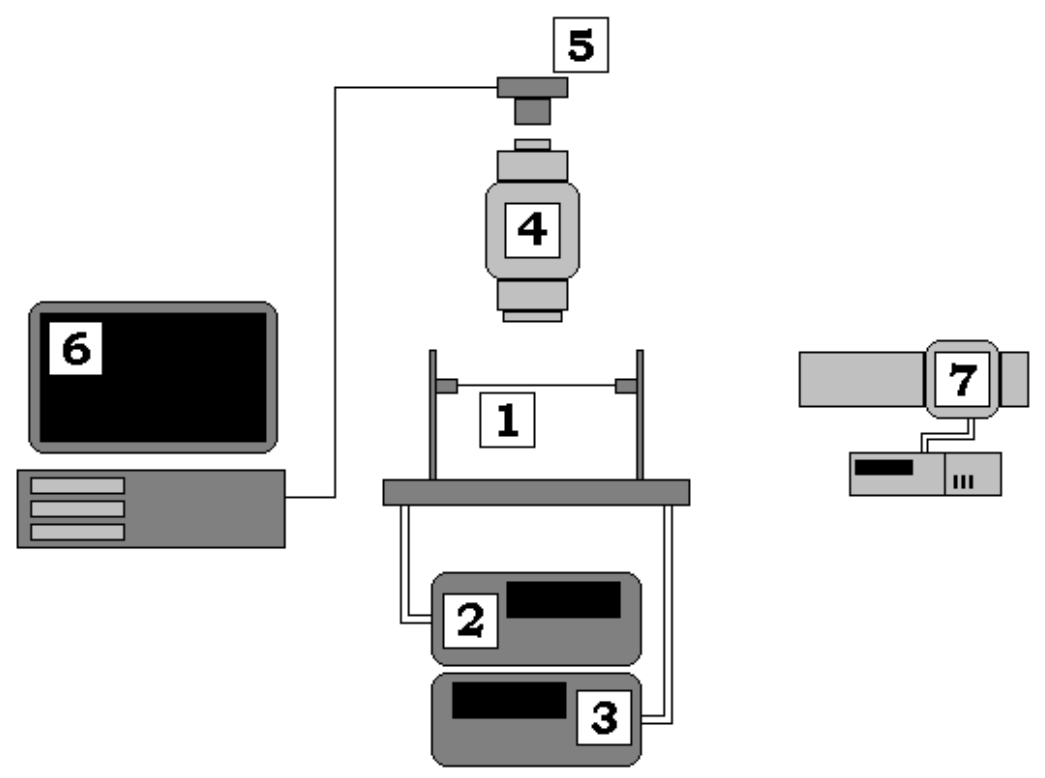

Fig.1. Experimental setup diagram

stabilized power supply (2). The voltmeter (3) recorded a voltage drop at its ends. The conductor surface was monitored in real time using a digital camera (5) mounted on an optical microscope (4). The image from the digital camera was fed to a personal computer (6). The surface temperature of the sample in the high temperature state was determined using a brightness pyrometer (7). Tungsten conductors of the VA brand with a diameter of $d=200 \mu \mathrm{m}$ and a length of $L=0.11 \mathrm{~m}$ were used for the studies. The experiments were carried out in air under normal conditions (pressure $p$ $=101.3 \mathrm{kPa}$, temperature $T_{g}=293 \mathrm{~K}$ ).

The stationary temperature regime was set by adjusting the current, which was gradually increased at certain time intervals, until the appearance of oxide crystalline formations on the surface. After that, at a fixed amperage, the growth of individual oxide crystals on the surface of the conductor was observed.The temperature of an electrically heated tungsten conductor was determined from the temperature dependence of the specific resistance:

$$
T=\left(\frac{R}{R_{k}}-1\right)\left(\frac{1}{\gamma}-T_{0}\right)+\frac{R}{R_{k}} T_{k},
$$

where $R, R_{k}$ is the resistance of the conductor in a stationary state and at room temperature (before the start of the experiment), respectively, Ohm.

Thus, the set of these methods allowed to control the heating process of the conductor, to measure the temperature field, local and average temperature of the sample, to study the state of its surface and to observe the growth of structural formations.

3. Received results and their discussion. Using the developed experimental stand, the proposed methods were studied stationary modes of heat and mass transfer 

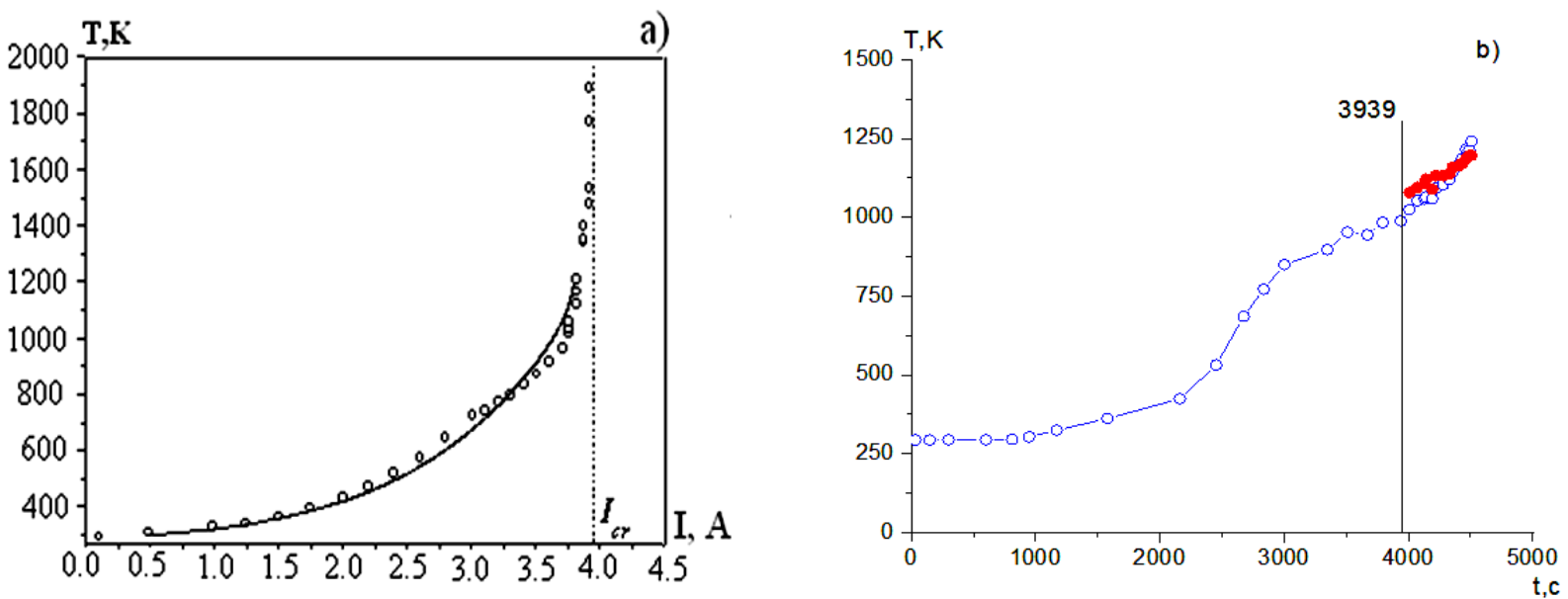

Fig.2. Dependence of the stationary temperature of the conductor on the current strength (a) and temperature on the time at the crystal growth stage (b). a) circles experiment,electrothermographic method; curve - calculation by the formula (9); b) experiment, $I=3.82 \mathrm{~A}$, filled circles - measurements with a brightness pyrometer.

and oxidation of tungsten conductor, heated by an electric current in the air. To do this, we heated the conductor at different current values. If after a while the current is set to almost constant temperature, then we observe a steady state. If, after another increase in current, the temperature of the conductor increases all the time, the heat and mass transfer mode ceases to be stationary and there is a transition to nonstationary oxidation, which ends with the burning of the conductor. The minimum value of the current at which the transition to a non-stationary oxidation regime is the critical value of the current $\mathrm{I}_{\mathrm{cr}}$, which characterizes the ignition.

Fig. 2a shows the dependence of the stationary temperature of the conductor on the heating current strength, obtained experimentally (circles) and calculated by the formula (9) (curve). There is good agreement between the experimental and theoretical results, which indicates the correct description of the thermal and kinetic mechanisms of the process. A sharp increase in temperature at a critical current strength $\mathrm{I}_{\mathrm{cr}}$ $=3.9 \mathrm{~A}$ is associated with a transition to a non-stationary mode of conductor oxidation and its further destruction. Near the critical conditions on the oxidized surface of the conductor, the formation of separate crystal structures was observed. The growth of crystals occurred at a fixed value of the current strength, but the conductor temperature continued to increase due to the heat release of the chemical oxidation reaction (fig. 2b).

The temperature of the conductor heated to a glowing state was also measured using an optical pyrometer (brightness pyrometer with a disappearing filament). In fig. $2 b$, filled circles represent the results of these measurements. They are in good agreement with the results of measurements by the electrothermographic method.

Digital images of an oxidized tungsten conductor under a microscope are shown in fig. 3a. It can be seen that the oxide is an uneven surface cut by grooves and cracks. On the surface of the conductor, separate structural formations are observed crystals of tungsten oxide, which have the form of thickened filaments. Mechanical processing of the conductor after the end of the experiment made it possible to 


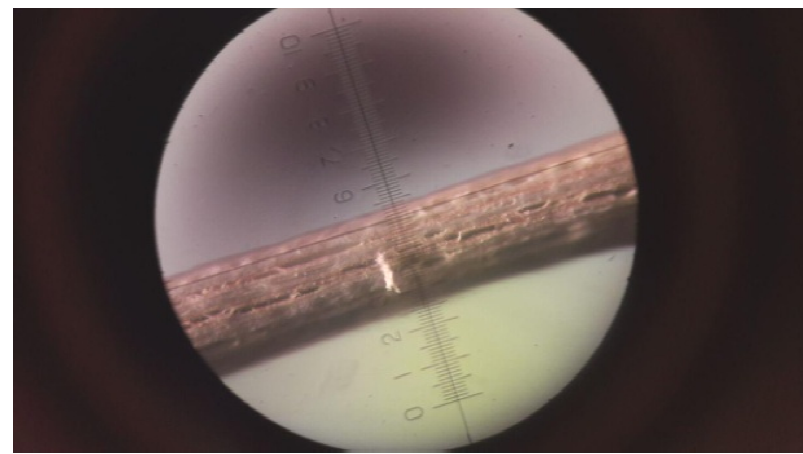

a)

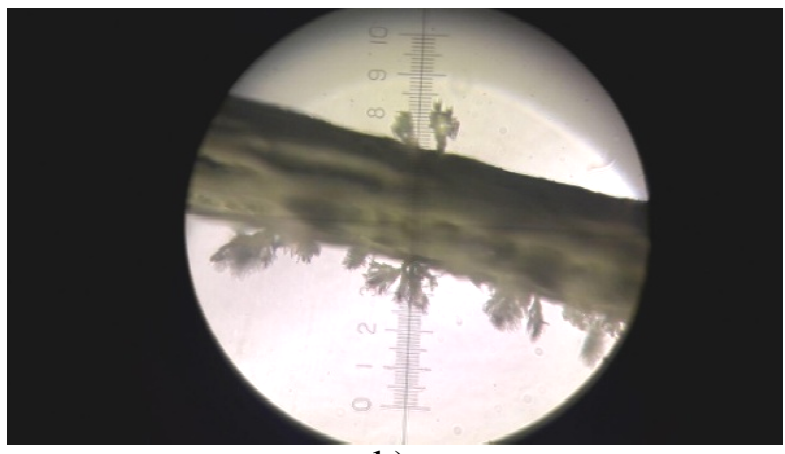

b)

Fig. 3. Images of the surface of an oxidized tungsten conductor during the experiment: a) the appearance of nitrate crystals, b) the branching of oxide structures

determine the thickness of the oxide layer. It turned out to be equal on average to 50$70 \mu \mathrm{m}$ in the central part of the conductor.

The study of the surface of tungsten conductors in stationary states in real time made it possible to detect the following picture of the formation of an oxide layer. At temperatures $T<900 \mathrm{~K}$, a continuous oxide layer appears on tungsten, separate grooves and irregularities appear. An important feature of the initial stage of oxide formation is that the surface of the metal is not clean. It already contains individual oxide nuclei, which are randomly distributed over the surface, possibly in places where there are surface imperfections, impurity atoms, and mechanical deformations.

Subsequently, at approximately average conductor temperatures $T \approx 900 \mathrm{~K}$, individual oxide crystals in the form of filaments and plates begin to appear on its surface (fig. 3a), which then grow into branchy formations (fig. 3b). By optical-digital method, it was found that the temperature of the surface of the conductor in the place of the formation of crystals exceeds $1100 \mathrm{~K}$. With an increase in temperature and oxidation time, the size of the crystals and their density on the surface of tungsten grow. Xray analysis of crystalline oxide structures showed that they consist predominantly of $\mathrm{WO}_{3}$.

Studies have been conducted aimed at clarifying the mechanism of formation of crystalline oxide structures on the surface of tungsten during heating. X-ray analysis of the initial samples showed that carbon impurities are present on the surface of the tungsten wire as a result of high-temperature wire drawing in the presence of graphite grease. Carbon is also found in oxide crystals on the branches of dendrite structures (fig.4a). An assumption arises that it is the carbon particles that cause the appearance of primary oxide crystals.

To verify this assumption, the oxidation of thoroughly cleaned conductors was investigated. For this, before the test, the sample surface was mechanically processed to a metallic luster. Also used and chemical processing path. As a result, it was found that branched oxide structures did not appear on the purified samples when heated.

Thus, carbon can be the center of crystallization of tungsten trioxide, which at temperatures above $900 \mathrm{~K}$ begins to sublimate from the metal surface. The condensation zone is formed near the surface of the conductor. Since the gas temperature near the surface is characterized by a high heterogeneity of several hundred degrees per 


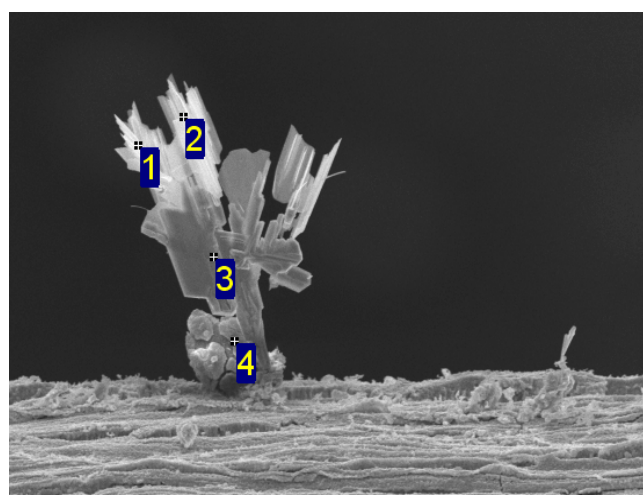

a)

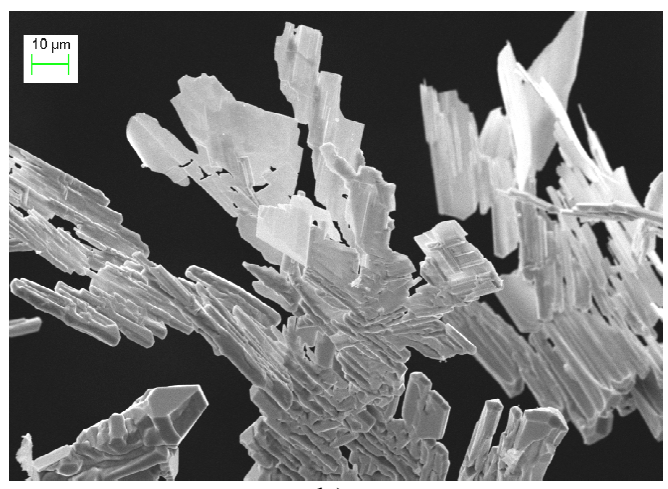

b)

Fig. 4. Images of oxide crystals on the surface of a tungsten conductor under an electron microscope: a) 1,2,3,4- points where carbon atoms are found, b) complex structure of crystal branches from individual granules.

millimeter (drops sharply), the distance from the surface of the $\mathrm{WO}_{3}$ oxide pair becomes supersaturated. Consequently, $\mathrm{WO}_{3}$ molecules, falling into the region with a lower temperature, begin to condense on carbon particles on the surface of a tungsten conductor. Thus, oxide crystals begin to form on the surface of carbon particles, which become centers of condensation of oxide molecules from the gas phase. The formation of filamentous tungsten trioxide crystals occurs.

Therefore, it can be assumed that the growth of crystalline oxide structures on the surface of the oxidized tungsten conductor occurs according to the «vaporcrystal» mechanism [8], and carbon particles ensure the formation of primary oxide dendrite structures.

In addition, it should be noted a high linear growth rate of branched oxide structures: an increase in the heating time of a conductor for several seconds leads to the formation of more branched oxide structures and the appearance of new crystals. It can be argued that in the gas phase homogeneous condensation of the oxide molecules occurs with the formation of clusters and $\mathrm{WO}_{3}$ microgranules. It is the construction of crystals, mainly from microgranules, that determines their rather high growth rate. Increasing the temperature of the wire due to the chemical oxidation reaction leads to an increase in the concentration of tungsten trioxide vapor. Due to this, branching of threadlike crystals occurs. Some crystals are formed by combining individual strands of oxide (fig. 4b). Branched bush-like structures are formed as a result of the sedimentation of a large number of tungsten oxide clusters.

The applied method of video surveillance of the crystals during their growth allowed us to study the shape and current dimensions of the crystals, as well as to determine the growth rate at certain stages. It is established that the general regularity of the formation of crystals is that the crystals first grew more intensively in the longitudinal direction (in height), and then in the transverse (in width). Some crystals grew unevenly: a decrease in the growth rate was observed, then the rate of branching increased. With increasing conductor temperature, due to oxidation, evaporation of individual crystals was also observed. This may be due to the melting of the main oxide layer on the surface of the conductor in some local areas. 
An analysis of the size of the crystals, which we carried out after the end of the experiment, showed that many crystals have a longitudinal dimension larger than the transverse one. This is due to the fixed height of the condensation zone at the surface of the conductor, the size of which depends on its temperature. Large temperature gradients at the surface of the conductor limit the growth of crystals in height. Expanding in the longitudinal direction, the crystals can overlap and, with a long duration of oxidation, merge with each other side faces.

It is established that the maximum growth rate of the geometric dimensions of tungsten oxide crystals under normal conditions in air is $0.4 \div 0.6 \mu \mathrm{m} / \mathrm{s}$. The height of the formed crystals can reach $200-250 \mu \mathrm{m}$.

Conclusions. The regularities of the formation and growth of oxide crystal structures on the surface of tungsten conductors, which are heated by an electric current in air, have been studied. It was found that in the presence of carbon particles on the surface of oxidized tungsten, whiskers of tungsten trioxide are formed, which subsequently, as a result of rapid growth, transform into branched crystal structures.

A mechanism for the formation and growth of branched oxide crystal microstructures on the surface of tungsten conductors when heated in air is proposed. As a result of oxidation, an oxide layer forms on the surface of tungsten, the outer part of which consists mainly of $\mathrm{WO}_{3}$. Tungsten trioxide sublimates into the surface layer from the surface of the oxidized conductor, and a condensation zone is created. At local temperatures on the surface of the conductor of about $1100 \mathrm{~K}$, the formation of crystals of a simple geometric shape begins: filamentous and lamellar. Vapors of $\mathrm{WO}_{3}$ oxide are condensed onto carbon nanoparticles present on the sample surface, after which the formation and growth of whiskers is observed. With an increase in the conductor temperature, due to oxidation, and an increase in the concentration of $\mathrm{WO}_{3}$ in the gas phase, branching of crystals occurs: growth in the transverse and longitudinal directions.

It was found that the maximum growth rate of the geometric dimensions of crystals under normal conditions in air is $0.4-0.6 \mu \mathrm{m} / \mathrm{s}$. The growth of crystals in the longitudinal direction is limited by the size of the condensation zone, in the transverse direction, by the overlapping of crystals with side branches with each other.

\section{Referenses:}

1. Barelko V.V., Abramov V.G., Merzhanov A.G. Thermographic method for studying the kinetics of gas-phase heterogeneous catalytic reactions//Journal of physical chemistry. - 1969. - T.XLIII, №11. - P.2828-2829. (in Russian).

2. Chernenko E.V., Rosenband V.I., Barzykin V.V. Study of the regularities of the ignition of zirconium in oxygen under pressure //Combustion, Explosion and Shock Waves. - 1979. - V.15, №4. - P.66-69. (in Russian).

3. Kofstad P. High-temperature oxidation of metals. - Moscow: Mir. - 1969. - 392 p. (Russian translation).

4. Benar J. Oxidation of metals. Vol.2. - Moscow: Publishing house "Metallurgy". - 1969. - 444 p. (in Russian, translation from French). 
5. Zhukauskas A.A. Convective transfer in heat exchangers. - Moscow: Nauka. 1982. - 472 p. (in Russian).

6. Orlovskaya S.G., Karimova F.F., Shkoropado M.S. Investigation of hightemperature modes of heat and mass transfer of tungsten conductors heated by electric current// Journal of Engineering Physics and Thermophysics. - 2011. - T.84, №2. - P. 368-373. (in Russian).

7. Orlovska S.G., Shkoropado M.S., Karimova F.F. Kinetics of the growth of oxide structures on the surface of refractory metals during heating in the ground// Phys. Chem. Solid St. - 2012. - Vol.13, № 3. - P.733-737. (in Ukraine).

8. Givargizov E. I. Growth of filamentous and lamellar crystals from steam.Moscow: Nauka. - 1977. - 303 p. (in Russian).

\title{
Орловская С.Г.
}

\section{Физико-химические механизмы роста кристаллов оксида на поверх- ности вольфрамовых проводников, нагреваемых электрическим то- КоМ}

\begin{abstract}
АННОТАЦИЯ
Проведено физико-математическое моделирование стационарных тепловых режимов нагрева и окисления вольфрамовых проводников, нагреваемых электрическим током в воздухе. Получены зависимости стационарной температуры проводника от силы нагревающего тока, найдены критические значения силь тока, определяющие переходы к нестационарному режиму окисления. Результаты расчета температурных режимов хорошо описывают экспериментальные данные, полученные нами с использованием электротермографического метода.

В результате экспериментальных исследований изучены особенности образования и роста кристаллических оксидных структур на поверхности окисляющегося вольфрамового проводника. Определены температуры, при которых на поверхности вольфрама возникают ниттевидные кристаллы, исследованы закономерности их роста. Предложен физико-химический механизм образования и роста кристаллических оксидных структур на поверхности вольфрамового проводника. Установлено, что частищь углерода, которые входят в состав примеси, являются причиной образования на основном оксиде ниттевидных кристаллов триоксида вольфрама. Найдены скорости роста кристаллических структур в продольном и поперечном направлениях.

Ключевые слова: тепло и массообмен, окисление, температура, вольфрам, окисд вольфрама, кристалл.
\end{abstract}




\title{
Орловська С.Г.
}

\section{Фізико-хімічні механізми росту кристалів оксиду на поверхні вольф- рамових провідників, що нагріваються електричним струмом}

\begin{abstract}
АНОТАЦІЯ
Проведено фізико-математичне моделювання стаціонарних теплових режимів нагріву і окислення вольфрамових провідників, щз нагріваються електричним струмом в повітрі. Отримано залежності стаціонарної температури провідника від сили нагріваючого струму; знайдено критичні значення сили струму, що визначають переходи до нестаціонарному режиму окислення. Результати розрахунку температурних режимів добре описують експериментальні дані, отримані нами з використанням електротермографічного методу.

В результаті експериментальних досліджень вивчено особливості утворення $i$ зростання кристалічних оксидних структур на поверхні окисленого вольфрамового дротика. Визначено температури, при яких на поверхні вольфраму виникають ниткоподібні кристали, досліджено закономірності їх росту. Запропоновано фізикохімічний механізм утворення $i$ зростання кристалічних оксидних структур на поверхні вольфрамового провідника. Встановлено, щуо частинки вуглецю, які входять до складу домішки, є причиною утворення на основному оксиді ниткоподібних кристалів триоксида вольфраму. 3 підвищенням температури зразка нитки ростуть, розгалужуються і перетворюються в дендритні структури складної кущьооодібної форми. Доведено, щь швидке зростання кристалічних структур відбувається внаслідок осадження кластерів і мікрогранул оксиду $\mathrm{WO}_{3}$ з газової фази на иентри кристалізації на поверхні провідника. На початковому етапі - це частинки домішки або механічні неоднорідності основного оксиду, потім - зростаючий кристал. Кластери виникають через великі температурні градієнти біля поверхні провідника. Встановлено, щзо атоми вуглечю можуть мігрувати по гілках оксидних кристалічних структур.

Встановлено, що на початковому етапі кристали інтенсивніше ростуть в поздовжньому напрямку. Однак, при досягненні певної висоти починають інтесивно розширюватися в поперечному напрямку. Знайдено швидкості росту кристалічних структур в поздовжньому і поперечному напрямках.
\end{abstract}

Ключові слова: тепломасообмін,окислення, температура, вольфрам, оксид вольфраму, кристал. 